\title{
Volatility Estimation and Stock Price Prediction in the Nigerian Stock Market
}

\author{
Ajao Mayowa Gabriel (Corresponding author) \\ Dept of Banking \& Finance \\ Faculty of Management Sciences \\ University of Benin \\ Benin-City, Edo-State, Nigeria \\ E-mails: mayourwah@yahoo.com,ajao.mayowa@uniben.edu \\ Wemambu Mary Ugochukwu \\ Dept of Banking \& Finance \\ Faculty of Management Sciences \\ University of Benin \\ Benin-City, Edo-State, Nigeria
}

Received: October 3, 2011

Accepted: November 7, 2011 Published: January 5, 2012

doi:10.5430/ijfr.v3n1p2

URL: http://dx.doi.org/10.5430/ijfr.v3n1p2

\begin{abstract}
This study aimed at understanding the Nigerian Stock Market with regards to volatility and prediction, to this effect the month end stock prices of four major companies from the period January 2005 to December, 2009 was used as proxy. The study made use of the Autoregressive Conditional heteroskedasticity (ARCH) to estimate and find out the presence of volatility. The study found the presence of volatility in all the four stock prices used, while stock price volatility was then regressed against stock prices to determine their predictability. The results however, revealed that out of the four companies, only two companies' stock prices were predicted by volatility in their stock prices, while past stock prices predicted current stock prices implying that the market does not follow a random walk. As a result of these, it is recommended that activities of corporate insiders should be properly checked, to reduce the predictability of stock prices, information should be known and made public to all investors. Also policy makers are advised to review their economic policies and should be careful in their use of the Nigerian bourse as a barometer to reflect performance in the general economy as our findings suggests that this could be misleading.
\end{abstract}

Keywords: Stock Prices, Volatility, Prediction, Random Walk, ARCH Model

\section{Introduction}

A number of recent studies have sought to characterize the nature of financial market return process, which has always been described as a combination of drift and volatility. Volatility may impair the smooth functioning of the financial system and adversely affect economic performance (Rajni and Mahendra, 2007; Mollah, 2009). Stock price volatility is an indicator that is most often used to find changes in trends in the market place. The increase or decrease in volatility results from changes in investors emotions in the market place. Stock price volatility tends to rise when new information is released into the market, however the extent to which it rises is determined by the relevance of that new information as well as the degree in which the news surprise investors. However, economists and financial experts have propounded theories on what causes volatility. Some financial economists see the causes of volatility embedded in the arrival of new, unanticipated information that alter expected returns on a stock (Engle, 1982). Others claim that volatility is caused mainly by changes in trading volume, practices or patterns, which in turn are driven by factors such as modifications in macroeconomic policies, shift in investors' tolerance of risk and increase uncertainty (Rajni and Mahendra, 2007).

Furthermore, stock market volatility has a number of negative implications. One of the ways in which it affects the economy is through the effect on consumer spending. (Campbell, 1996; Star McCluer, 1998; Ludrigson and Standel, 1999; Poterba, 2000; and Rajni and Mahendra, 2007). A fall in stock market prices will weaken consumer confidence 
and thus drive down consumer spending (Rajni and Mahendra, 2007). Stock market volatility may also affect business investments (Zuliu, 1995) and economic growth directly (Levine and Zervous, 1996). A rise in stock market volatility can often be interpreted as a rise in equity and thus a shift of funds to less risky assets, this move have been known to lead to a rise in the cost of funds to firms and thus new firms (new entrants) might bear this effect as investors turn to the purchase of stocks in largely, well known firms (Rajni and Mahendra, 2007).

The understanding of volatility in a stock market will be useful in the determination of the cost of capital and in the evaluation of asset allocation decision. Policy makers therefore rely on market estimates of volatility as a barometer of the vulnerability of financial markets (Olowe, 2009). However, the existence of excessive volatility in the stock market undermines the usefulness of stock prices as a signal about the true intrinsic value of a firm, a concept that is core to the paradigm of the informational efficiency of markets (Karolyi, 2001). In Nigeria, activities of the recent past such as the recapitalization of the banking industry in July, 2004 and the insurance industry in September, 2005 boosted activities through the number of securities listed on the stock market, increasing public awareness and confidence about the stock market. The increased trading on the stock market could have affected the volatility of the stock market. However, investors have recently been worried about the falling stock prices on the Nigerian stock market (Olowe, 2009). Also, the Nigerian stock market is a developing and inefficient one characterized by the time lag between information availability about a stock and its full reflection in the price of the stock, poor infrastructural facilities in the country which makes it virtually impossible for information to flow freely and speedily to actual and potential investors, activities of corporate insiders and insider abuses.

Hence, an understanding of volatility and stock price prediction in Nigerian stock market will be imperative as it helps in predicting the path of its economy's growth and determines the efficiency of the stock market which will serve as an indicator of economic growth and development in Nigeria and in turn attract foreign portfolio investment. The scope of this study is limited to the Nigerian capital market with special reference to the stock prices of selected companies in the Banking, Brewery, Food and Beverage and Petroleum Industry. For the study, month end stock prices were analysed for the period spanning January 2005 to December, 2009.

The remaining sections of this paper are organized as follows: A review of related literatures was carried out in section two. The focus of section three is the research methodology, estimation techniques, analytical tools, data collection and data requirements. Section four is concerned with data analysis as well as the various data presentation techniques used. The summary and conclusion from the study, recommendation offered is covered in section five.

\section{Review of Related Literatures}

Volatility is simply defined as a measure of dispersion around the mean or average return of a security. It is a measure of the range of an asset price about its mean level over a fixed amount of time (Abken and Nandi, 1996). It follows that volatility is linked to the variance of an asset price. If a stock is labeled as volatile then the price will vary greatly over time. Conversely, a less volatile stock will have a price that will deviate relatively little over time. Volatility is calculated as the standard deviation from a certain continuously compounded return over a given period of time. It is an important measure of quantifying risk, for example, a security with a volatility of $50 \%$ is considered very high risky because it has the potential to increase or decrease up to half its value. Volatility is a measure of risk based on the standard deviation of the asset return. It is a variable that appears in option pricing formulas, where it denotes the clustering of the underlying asset return from now to the expiration of the option (Karolyl,2001;Mordi,2006).

Stock prices are characterized by volatility when significant changes occur, investors tend to panic. Different factors influence the movement in stock prices. Notable among these factors are: arrival and disclosure of new information, demand and supply forces, investor psychology, economic strength of the market, uncertainty about the future economic outlook.

\subsection{Stock Price Prediction}

Stock price prediction is the act of trying to determine the future value of a company stock or other financial instruments traded on a financial exchange. The successful prediction of a stock's future price could yield significant profit. Some believe that stock price movement are governed by the random walk theory and thus unpredictable. Others disagree and those with this view point possess a myriad of methods and techniques which purportedly allow them to gain future price information. Within the last two decades, a great deal of attention has been focused on the idea of predicting stock prices and price fluctuations (Wojciech, 2007). In this regard, a look at the degree or extent to which already existing theories have effectively succeeded in predicting stock prices will be imperative.

The widely accepted theory of how the stock market works is the efficient market hypothesis (Warneryd, 2001) and in its simplest form, states that stock prices always reflect all the available information about the market and companies in 
question. The theory also assumes that every investor has access to all the required information to value a stock. This problem of "perfect information" is its interpretations while financial statements and economic statistics are widely available, one cannot assume that such information is interpreted correctly by all investors (Dyckman and Morse, 1986). Indeed this interpretation often depends on how information is framed and where it comes from (Shleifer, 2000). Furthermore, well documented stock market anomalies such as an increase in share prices in January and a continuation of Friday price trends on Mondays run counter to the idea of unpredictable and perfectly efficient markets (Dimson, 1988). In terms of large groups, one of the major problems with the EMH is that the assumptions imply investors act independently of each other: a naïve investor making mistakes will be taken advantage of by a rational investor. However, it is often the case that investors act in unison as can be seen during periods of irrationally increasing prices (Shlefier, 2000).

Fundamental and technical analyses are other means of predicting stock prices. Whereas, fundamental analysis looks at many different aspects of a company, industry and economy to identify factors that influence stock prices, their behavior and movements for the purpose of predicting how well a stock will perform in the future. Technical analysis is often defined as "the process of analyzing a security's historical data (prices and volume) in an effort to determine probable future prices" (Achelis, 2001; Murphy,1986).Proponents of the technical factors that influence stock price movements in a market hold that fundamental factors are indeed important and reflected in the price behavior of stocks in the market. They however argued that psychological and other factors like investors' emotions which epitomized in the sometimes irrational behaviour of investors are also important in determining the behaviour of stock prices in the market. Thus it is possible to predict the future of a stock by a diligent and painstaking study of the historical price movements of the stock in the market (Osaze, 2007).

The use of technical analysis within investment decisions has been controversial. According to efficient market hypothesis, investors act completely rational and have access to all required information to value a stock's price during the present as such, a stock's current price reflects its value at that time, and has no connection with past prices. Such assumptions have been criticized and statistical analyses of technical indicators have shown their usefulness in predicting trend reversals and share price fluctuations (Brock, Lakonishok and Le Baron, 1992). One of the problems with technical analysis is that while so many tools exist, many of the details are subjective, it is still up to the investor to choose values for the variables with each tool, and it is the investor's decision to follow a buy or sell signal from a technical indicator.

Inspite of the arguments of the technical and fundamental analyses about the price behaviour of stocks in the market upon which profits can be made, there is the major underlying theory of stock price behaviour which contends that the market is efficient that one cannot beat it with any of the techniques discussed so far. This is the Random Walk Theory. The central idea behind the random walk theory is that the randomness of stock prices renders any attempts to find price patterns or take advantage of new information futile. In particular, the theory claims that day to day stock price movement are independent of each other because there is no serial correlation between price changes from one period to another, meaning that momentum does not generally exist and calculations of past earnings growth does not predict future growth (Malkiel, 1973;2003).

\subsection{Theoretical Framework}

Prediction of stock prices is generally believed to be a very difficult task if a nation's economy is being affected by inflation and fluctuations of exchange rate .In recent years, the role of information in pricing of stock has attracted wide interest in areas of finance and economic literatures (Okan et al, 2009). This attention has been driven by the recent advances in market microstructure literature which greatly enhances our understanding of the incorporation of information into asset price and volume. As documented widely in finance literature, trading volume and price volatility display a positive correlation. Schwert (1989) evidenced a positive relationship between estimated volatility and current and lagged volume growth rates through the linear distributed lag and VAR model for the monthly aggregates of daily data on Standard and Poor (S\&P) index. Lamoureux and Lastrapes (1990) in a seminar work using the individual stocks from the S\&P index, reported a positive conditional volatility - volume relationship in models with the Gaussian errors and GARCH type volatility specifications. One of the earlier models to explain the positive volume and volatility correlation is mixture of distribution hypothesis that posits a joint dependence of returns and volume of an underlying latent event or information flow variable. That is both trading volume and price respond contemporaneously to new information (Clark, 1973, Epps and Epps, 1976, Tauchen and Pitts, 1983, Harris, 1986).

Many financial time series have been modeled by the use of GARCH model (Bollerslev, 1986). Thus, the GARCH effect is explained by considering the rate of arrival of information flow as the mixture variable. Accordingly, Brailsford (1996) tested the relationship among the trading volume and conditional return volatility in Australian stock market 
using the GARCH $(1,1)$ model. He concluded that for absolute returns, the results provide a strong support to the inferences of Lamoureux and Lastrapes (1990). In contrast, some of the latter studies (Chen et al, 2001; Aroga and Nieto, 2004) suggest no reduction in the persistence of volatility. Sequential information arrival hypothesis is another framework to explain volume and volatility correlation developed and extended by the studies of Copeland (1976), Jennings et al., (1981), Jennings and Barry (1983) and Samlock and Starks (1985). In this model, new information is disseminated sequentially to investors. Thus, the correlation between trading volume and price volatility arises in a sequential manner.

Akgiray (1989) presented evidence about the time series behaviour of stock prices. Daily return series exhibited significant levels of second-order dependence and they could not be modeled as linear white-noise processes. A reasonable return-generating process was empirically shown to be a first-order autoregressive process with conditionally heteroskedastic innovations. Corhay and Rad (1994) indicated that conditional hereroskedasticity was a prime feature of daily returns behavior of five European equity indices. They exhibited non linear dependence that could not be captured by the random walk model. The class of autoregressive conditional heteroskedastic models was generally consistent with the stochastic behavior of these return series. The evidence presented by them revealed that the GARCH-t $(1,1)$, i.e. a GARCH model with conditional errors that were t-distributed, fitted the data best. Thus, their results confirmed that this class of models was appropriate for studying the behavior of stock returns on a small equity market. They also supported that GARCH model could indeed provides better forecasts of volatility than the usual historical estimates and lead to improved valuation models.

While most empirical studies have been limited to the US and European markets, limited number of researchers have applied the literatures by examining trading volume, price (return) and volatility relationships in emerging markets. Moosa and Al-Loughani (1995) used monthly data to examine four Asia stock markets which are Malaysia, Philippines, Singapore and Thailand, while Saatcioglu and Starks (1998) scrutinsed six Latin American stock markets that are Argentina, Brazil, Chile, Colombia, Mexico and Venezuela. Besides Baklaci and Kasman (2007) examined the 25 individual stocks traded in Istanbul stock exchange in this respect. Furthermore, Olowe (2009) examines volatility in the Nigerian stock market. In brief, it is generally accepted that there is a relationship between trading volume and price volatility indicated by different models and methods.

\section{Research Methodology}

The longitudinal survey research design was adopted for this study, because stock price movements in the selected companies over time were studied and the data was collected at different points in time without any attempt to influence them. Data obtained showed changes in the variables (stock prices) of interest over time. The population of the study comprises of all quoted firms in the Nigerian Stock Exchange between January, 2005 to December, 2009.However,four major companies (First bank, Nigerian breweries, Nestle foods and Mobil petroleum) based on trading volumes and active industrial classification constitute the sample of this study. The data collected and used for this study were obtained from secondary sources. The data comprises of the month end stock prices covering January, 2005 to December, 2009. The data were obtained from the official website of Cash Craft Asset Management (member of the Nigerian Stock Exchange).

\subsection{Model Specification}

In other to estimate volatility and predict stock prices in Nigeria stock market, we adopted two models:

\subsubsection{Model 1: Estimation of Volatility}

Following the literature on volatility measurement we used an ARCH (2) model in testing for the presence of volatility in the selected sample companies stock prices.

The ARCH (2) model is given as follows:

$P_{t}=\mathrm{sx}_{0}+e_{\mathrm{t}}$

Estimating equation (1) using a regression techniques and obtaining the error term $\left(\mathrm{e}_{\mathrm{t}}\right)$

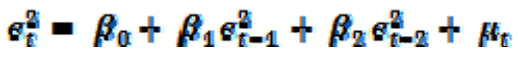

Equation two (2) test for the presence of ARCH effect and the presence of ARCH effect implies that there exist cluster or volatility in a time series.

In measuring volatility in stock market prices we adopted ARCH (1) model and the estimation prices is shown as follows:

$P_{t}=\beta_{1}+t_{t}$ 
Thus, $\mu_{\mathrm{t}}$ is the mean adjusted relative change in the time series. Now we can use $\mu_{\mathrm{t}}^{2}$ as a measure of volatility. Being a squared quantity, the value will be high in periods when there are big changes in the price of financial assets and its value will be comparatively small when these are modest changes in the prices of financial assets.

\subsubsection{Model II: Prediction of Stock Prices}

The stock price prediction model that integrates volatility will be specified as follows;

$\boldsymbol{P}_{\mathrm{r}}=\pi_{0}+\pi_{1} \boldsymbol{P}_{t-1}+\pi_{2} \boldsymbol{P}_{t-2}+\pi_{3} U_{t}^{2}+\phi$

This model suggests that stock market price prediction depends on past stock prices (i.e. the random walk hypothesis does not hold) and stock price volatility.

Where:

$\mathrm{P}_{\mathrm{t}}=$ Current stock prices of selected company

$\mathrm{P}_{\mathrm{t}-1}=$ Past stock prices such that

$\mathrm{P}_{\mathrm{t}-1}$ (1 year lag stock prices) and

$\mathrm{P}_{\mathrm{t}-2}$ (2 years lag stock prices.

$\mathrm{U}_{\mathrm{t}}^{2}=\mathrm{ARCH}$ measure of stock price volatility.

Hypothesis

$\mathrm{H}_{01}$ : That there is no significant indication of volatility in Nigerian Stock market.

$\mathrm{H}_{02}$ : That there is no significant relationship with the level of volatility and stock price prediction in Nigerian stock market.

\subsection{Method of Data Analysis}

The focus of this study is to support or refute the volatility of stock prices in the Nigerian stock exchange. To achieve this, the Auto Regressive Conditional Heteroskedasticity [ARCH] models introduced by Engle (1982) were employed. The appeal of the model is that it captures both volatility clustering and unconditional returns distribution with heavy tails.

\section{Presentation and Analysis of Results}

\subsection{Models}

\section{Model 1: Estimation of Volatility}

The mean and standard deviation tends to capture volatility in stock prices and it is a dispersion or variation from the norm. A high standard deviation is indicative of a higher volatility while a lower standard deviation indicates a lower volatility in the prices of stocks. Based on Table I, out of the four companies analyzed Mobil oil and Nestle stock prices have higher level of volatility because the estimated standard deviation are 63.01 and 42.05 respectively which are higher than other companies standard deviation. Hence, it can be deduced that the prices of First Bank and Nigerian Brewery stocks are more stable compared to that of Mobil and Nestle during the period under consideration while there is higher degree of dispersion in the price of Mobil and Nestle stocks during the same period.

Following the results in Table 2, we can deduce that there is ARCH effect in the stock prices of the four selected companies. This is because the t-values are 7.4662, 3.9916, 4.1981 and 3.5266 respectively and statistically significant at $5 \%$ level as each of this value is higher than t-critical value of 2.000 . Besides since the value of $\mathrm{e}_{\mathrm{t}}^{2}$ is not equal to the value of the intercept $\left(\propto_{0}\right)$, it shows the presence of the ARCH effect.

\section{Model II: Stock Price Prediction}

Following the results in Table 3, which represent the prediction of stock prices. The result shows that about $67 \%, 77 \%$, $56 \%$ and $65 \%$ of the systematic variations in Mobil, First bank, Nigeria Brewery and Nestle stocks prices respectively are explained by past stock prices $\left(\mathrm{P}_{\mathrm{t}-1}\right.$ and $\left.\mathrm{P}_{\mathrm{t}-2}\right)$ and stock price volatility. The $\mathrm{F}$ statistic in the model shows that the model is generally significant since the F-calculated value for each of the four stocks is greater than their respective F-critical values at 5\% level of significance. In predicting the stock prices of each of the four firms under consideration, the result shows that one period lag (past) stock price had positive and significant impact on current prices as the t-values of $-7.1376,-7.099,-5.366$ and -5.4690 for Mobil, First bank, Nigeria Brewery and Nestle stocks respectively were all greater than t-critical of -2.000 at $5 \%$ level of significance. In the case of the second period lag (past) stock price impact on the current stock price was statistically insignificant for all the four stocks because the t-values of 
$-1.3997,-0.2436,-0.2558$ and -0.3509 each is less than the critical value of -2.000 at $5 \%$ significance level. However volatility in stock prices as an explanation of current stock prices was statistically insignificant for Mobil and Nigerian brewery stocks as their individual t-value of -0.2037 and -0.369 respectively is less than the critical value, however, such volatility in stock prices as an explanation of current stock prices was statistically significant for First bank and Nestle stocks. From the aforementioned, there is therefore empirical evidence to state that random walk hypothesis does not hold in any of the four stocks analyzed (which can therefore be generalized for the entire Nigerian stock market). Besides, while stock market price volatility significantly drives First bank and Nestle stocks prices, it does not drives Mobil and Nigeria brewery stocks prices during the period under consideration.

\subsection{Hypothesis Testing}

In testing the hypothesis of the study, the F statistic was used. The study adopted 5\% level of significance.

$\mathrm{Ho}_{1}$ : There is no significant indication of volatility in Nigerian stock prices.

The empirical result from ARCH (2) for each of the four stock prices analyzed showed that the F calculated values were all greater than their respective critical values. Therefore the null hypothesis is rejected and the alternative hypothesis is accepted which states that there exist significant indications of volatility in Nigerian stock prices.

$\mathrm{H}_{\mathrm{o} 2}$ : There is no significant relationship with the level of volatility and stock price prediction in the Nigerian stock market.

The empirical result from ARCH (1) for First bank and Nestle stocks showed that their t-calculated value is greater than the t-critical value of 2.000 at $5 \%$ level of significance. Therefore the null hypothesis is rejected and the alternative hypothesis accepted which states that there exist a significant relationship with the level of volatility and stock price prediction in the Nigerian stock market. Whereas for Mobil and Nigerian brewery stocks, the analysis showed that their t-calculated values are less than the t-critical value at $5 \%$ level of significance, therefore we reject the alternative hypothesis and accept the null hypothesis which states that there was no significant relationship with the level of volatility and stock price prediction in the Nigerian stock market. In conclusion, it was observed that while volatility could not predict current stock prices of some companies, in other cases volatility predict current stock prices of other companies.

\section{Summary of Findings}

This study investigates the relationship between the level of volatility and stock price prediction in Nigeria and the presence of volatility in stock market prices. Several findings and implication are derived from the model estimation. It was found that the Nigerian stock market prices shows persistence or indicated a high level of volatility (risk). The findings on the relationship between volatility and predicting stock prices were mixed. Based on the fact that Mobil and Nigerian Brewery stock prices volatility could not predict their current stock prices and hence volatility in these two cases, was insignificant and negative. While current stock prices of First bank and Nestle food was significantly predicted by volatility of these stocks thereby indicating a positive relationship.

One major deduction from the empirical result is that the conclusions of random walk hypothesis are, as expected thrown in doubts. The claim is consequent upon the evidence of past stock prices predicting current stock prices, as in the case of Mobil stock prices where past stock prices (one period lag) had positive and significant impact on current prices (t-value $7.1376>\mathrm{t}$-critical value 2.000 at $5 \%$ level). However this empirical evidence was present in all other three stocks analyzed. Primarily the movement of stock market prices may indeed be predicted, contrary to the efficient market hypothesis and random walk hypothesis conclusions. For this reason policy makers in Nigerian stock market may need to re-examine their economic policy.

However, these findings have important policy implications. For individual investors, volatility in a firm's stock price results in a stock price no longer seen as the true intrinsic value of the firm and thus investors might lose confidence in the stock market. Corporate investors should be well attuned to the development on the stock market and all available information pertaining to their investments because stock prices are very sensitive to this information. Hence a more informed portfolio management and selection should be encouraged for investors. Besides, investors can implement their own investment policy by studying the trend of volatility in the market over time in other to be able to predict stock price movement and gain fair superior advantage for trading actively on the Nigerian Stock Exchange. In essence volatility in stock prices becomes a tool that can be used to achieve desired economic objectives. However investors must be aware that, in inefficient stock market (like Nigerian stock exchange), heavy gains are just as likely as heavy losses. Also, these findings are important because they could be crucial in areas such as the design of stabilization and drafting of economic programmes and policies for the economy as a whole. Since policy makers in the financial sector play major role in influencing the expected return-risk premium and volatility of stock market, the results of this study 
will help investors and portfolio managers deepen their understanding of volatility (risk) and price relationship as well as diversification implication in Nigerian stock market.

\section{Recommendations}

From the findings of this study, the following recommendations are hereby suggested for policy implications. Information disclosure; availability of information on the attributes of firms is desirable in assessing the viability of these firms. As such information goes a long way in enhancing the efficient pricing of the securities of firms, companies in disclosing vital information concerning the state of affairs of their firms should also ensure that they are timely. This will help market participants in evaluating the performance of these firms and hence the pricing of their securities. Thus most information about the firms should not be the exclusive reserve of insiders.

The Nigerian Stock Exchange and the Securities and Exchange Commission should encourage the setting up of rating agencies which will be concerned primarily with analyzing the performance of firms and which will in turn help in the efficient price adjustment of securities in line with price mechanism.

Institutional investors, government and their agents are known to acquire large number of securities. Because of their buy and hold strategy, there is paucity of such securities. The demand for such security in the market is rarely or never met since there is no adequate supply. The absence of adequate supply negates the establishment of efficient price level(s) by the interaction of the forces of demand and supply. The market regulators should make a policy that would ensure that only a very small percentage of new issues are acquired by these groups of investors.

There should be more sustained effort on the part of government geared at providing basic infrastructural facilities that aid development and facilitate activities on the stock exchange as this will bring about increased access to new information by investors. The inadequate access to such facilities has hindered the growth and development of the Nigerian stock market thereby affecting the depth and breadth of the market. There is need to create a stable political environment free from terrorism and other vices in other for foreign investments (portfolio and listing) to strive in the stock market as this will boost the confidence of the international community in Nigerian stock market.

\section{Conclusions}

Volatility is a widely researched area in the finance literature. The performance of estimation models of varying complexity has been investigated according to a range of measures and generally mixed results have been recorded. The main thrust of this study is the empirical investigation of the indication of volatility and the relationship between volatility and stock price prediction as reflected in the general business and financial conditions in Nigeria capital market.

Despite other studies such as Samuels and Yacout (1981), Ayadi (1984), Olowe (1999) and Okpara (2010) discovered that the Nigerian stock market is efficient in the weak form and stock prices follows a random walk and hence cannot be predicted, suggesting that the opportunity to make excess return on the market does not exist. This study however, contradicted these findings by observing that stock prices in Nigeria-capital market do not follow a random walk and thus are predictable. However, the results and findings of this study discovered that the Nigerian Stock Exchange is not efficient in the weak form.

In conclusion, risk occurs to some degree in all investment markets, and volatility is one reflection of this risk. Contrary to popular opinion, volatility should not be feared; it should be recognized as a necessary part of the risk and return relationship. A reasonable amount of volatility in an investment is the trade off for higher long term returns expectations. Investors should not alter their asset allocation plan in response to short-term changes in volatility, but should review the reasonable long term expectations for volatility when creating their strategic assets allocation.

\section{References}

Abken, P. A. \& Nandi, S. (1996). “Options \& Volatility”. Economic Review; December,: 21-35.

Achelis, S. B. (2001). Technical Analysis from A to Z. New York: McGraw-Hill.

Akgiray, V. (1989). "Conditional Heteroskedasticity in Time Series of Stock Returns: Evidence \& Forecasts". Journal of Business, 62 :55-80. http://dx.doi.org/10.1086/296451

Aroga, V. \& Nieto, L. (2005). Heteroskedasticity in the Returns of the Main World Stock Exchange Indices: Volume versus GARCH Effects, Journal of International Financial Markets, Institutions \& Money, 15(3), 271-284. http://dx.doi.org/10.1016/j.intfin.2004.06.001

Ayadi, O. (1984). The R\&om Walk Hypothesis \& the Behaviour of Share Prices in Nigeria. Nig. J. Econ. Soc. Stud. 26(1) March. 
Baklaci, H. F. \& Kasman, A. (2006). An Empirical Analysis of Trading Volume \& Return Volatility Relationship in the Turkish Stock Market, Ege Akademik Bakis, 6:.115-126.

Bollerslev, T. (1986). Generalised Autoregressive Conditional heteroskedasticity, Journal of Econometrics, 31(1): 307-327. http://dx.doi.org/10.1016/0304-4076(86)90063-1

Brailsford, T. \& Faff, R. (1996). An Evaluation of Volatility Forecasting Techniques, Journal of Banking \& Finance, 20, 419-38. http://dx.doi.org/10.1016/0378-4266(95)00015-1

Brock, W., Lakonishok, L. \& LeBaron, B. (1992). Simple Technical Trading Rules \& the Stochastic Properties of Stock Returns. The Journal of Finance, 47, 1731-1764. http://dx.doi.org/10.2307/2328994

Campbell, J. (1996). "Consumption \& the Stock Market: Interpreting International Experience", NBER Working Paper, 5610.

Chen, G. M., Firth, M. \& Rui, O. M. (2001). The Dynamic Relation between Stock Returns, Trading Volume \& Volatility. The Financial Review, 30:153-174. http://dx.doi.org/10.1111/j.1540-6288.2001.tb00024.x

Clark, P. K. (1973). A Subordinated Stochastic Process Model with Finite Variance for Speculative Prices, Econometrica,41(1):135-155. http://dx.doi.org/10.2307/1913889

Copeland, T. E. (1976). A Model of Asset Trading Under the Assumption of Sequential Information Arrival, Journal of Finance. 31:1149-1168. http://dx.doi.org/10.2307/2326280

Corhay, A. \& Rad, A. T. (1994). "Statistical Properties of Daily Returns: An Evidence from European Stock Markets", Journal of Economies Finance \& Accounting, 2:271-281.

Dimson, E. (1988). Stock Market Anomalies. Cambridge: Cambridge University Press.

Dyckman, T. R. \& Morse, D. (1986). Efficient Capital Markets \& Accounting: A Critical Analysis. United States: Prentice Hall.

Engle, R. F. (1982). Autoregressive Conditional Heteroscadasticity with Estimates of the Variance of the U.K. Inflation, Econometrica, 50(3): 987-1008. http://dx.doi.org/10.2307/1912773

Epps, T. W. \& Epps, M. L. (1976). The Stochastic Dependence of Security Price Changes \& Transaction Volumes: Implications for the Mixture-of-Distribution Hypothesis, Econometrica,44(2) 305-321. http://dx.doi.org/10.2307/1912726

Fama Eugene, F. (1979). "Efficient Capital Markets: A Review of Theory \& Empirical Work". Journal of Finance, 25(2), 383-417. http://dx.doi.org/10.2307/2325486

Harris, L. (1986). Cross-SecurityTests of the Mixture of Distributions Hypothesis.Journal of Financial \& Quantitative Analysis 21:39-46. http://dx.doi.org/10.2307/2330989

Jennings, R. H. \& Barry, C. (1983). Information Dissemination \& Portfolio Choice, Journal of Financial \& Quantitative Analysis, 22,143-161.

Jennings, R. H., Starks, L. T. \& Fellingham, J. C. (1981). An Equilibrium Model of Asset Trading with Sequential Information Arrival, Journal of Finance, 36,143-161. http://dx.doi.org/10.2307/2327469

Karolyi, G. A. (2001). "Why Stock Return Volatility Really Matters". Paper Prepared for Inaugural Issue of Strategic Investor Relations, Institutional investors Journals Series, February.

Lamourex, G. C. \& Lastrapes,W. D. (1990). "Heteroskedasticity in Stock Returns Data: Volume Versus GARCH Effects". Journal of Finance, XLV,221-229. http://dx.doi.org/10.2307/2328817

Levine, R. \& Zervos, S. (1996). "Stock Market Development \& Long-Run Grown. World Bank Economic Review, 10(1): 323-339.

Ludvigson, S. \& Steindel, C. (1999). "How Important is the Stock Market Effect on Consumption" Federal Reserve Bank of New York Economic Policy Review, 5(1): 29-51.

Malkiel, B. G. (1973). A Random Walk Down Wall Street: The Time Tested Strategy for Successful Investing; New York: Princeton University Press.

Malkiel, B. G. (2003). The Efficient Market Hypothesis \& its Critics. Journal of Economic Perspectives, 17, 59-82. http://dx.doi.org/10.1257/089533003321164958

Mollah, S. A. (2009). "Stock Return \& Volatility in the Emerging Stock Market of Bangladesh". Journal of the 
Academy of Business \& Economics, 43 (2),29-78.

Moosa, I. A. \& Al-Loughani ,N. E.(1995). Testing the Price-Volume Relation in Emerging Asian Stock Markets, Journal of Asian Economics, 6,407-422. http://dx.doi.org/10.1016/1049-0078(95)90007-1

Mordi, F. I. (2006). Behaviour of Share Prices in the Nigerian Stock Market \& the R\&om Walk Hypothesis: University of Nigerian Research Publications.

Murphy, J. J. (1986). Technical Analysis of the Futures Market, NYIF: New York, 2-4.

Okan, B., Ogun, O., \& Takmaz, S. (2009). Volume \& Volatility: A Case of ISE - 30 Index Futures". Int. Research Journal of Finance \& Economics. 32, 93-102.

Okpara, G. C. (2010). "Stock Market Prices \& the R\&om Walk Hypothesis". Journal of Economies \& International Finance, 2(3),049-057.

Olowe, R. A (1999). Weak form Efficiency of the Nigerian Stock Market Further Evidence, African Development Review. 11(1);54-68. http://dx.doi.org/10.1111/1467-8268.00003

Olowe, R. A. (2009). :Stock Return, Volatility \& the Global Financial Crisis in An Emerging Market: The Nigerian Case", International Review of Business Research Papers,5.426-447.

Osaze, B. E. (2007). "Capital Market, African \& Global: Lagos, Bookhouse Company.

Poterba, J. M. (2000). "Stock Market Wealth \& Consumption", Journal of Economic Perspectives, 14(2):99-119. http://dx.doi.org/10.1257/jep.14.2.99

Rajni, M. \& Mahendra, R. (2007). Measuring Stock Market Volatility in an Emerging Economy. International Research Journal of Finance \& Economics 8,126-133

Saatcioglu, K. \& Starks, L. T. (1998). The Stock Price-Volume Relationship in Emerging Stock Markets: The Case of Latin America, International Journal of 14,215-225. http://dx.doi.org/10.1016/S0169-2070(98)00028-4

Samuels, J. M. \& Yacout, N. (1981). Stock Exchange in Developing Countries, Savings \& Development. 4, 217-320.

Schwert, G. W. (1989). "Stock Volatility \& Crash of 87", Review of Financial Studies, 3, 77-102. http://dx.doi.org/10.1093/rfs/3.1.77

Shleifer, A. (2000). Inefficient Markets: An Introduction to Behavioural Finance. Oxford: Oxford University Press.

Smirlock, M. \& Stark, L. T. (1985). A Further Examination of Stock Price Changes \& Transaction Volume, Journal of Financial Research,8, 217-225.

Starr-McCluer, M. (1998). "Stock Market Wealth \& Consumer Spending”. Board of Governors of the Federal Reserve System,Finance \& Discussion Paper Series 98/20

Tauchen, G.\& Pitts, M. (1983). ThePrice Variability-Volume Relationship on Speculative Market Econometrica 51:485-505

Warneryd, K. E. (2001). Stock-Market Psychology. United Kingdom: Edward Elgar.

Wojciech, G. (2007). "Neural Network Predictions of Stock Price Fluctuations".

Zuliu, H. (1995). “Stock Market Volatility \& Corporate Investment”, IMF Working Paper, 95/102.

Table 1. Stock prices statistics

\begin{tabular}{|c|c|c|c|c|c|}
\hline & Mobil & First Bank & $\begin{array}{c}\text { Nigeria } \\
\text { Brewery }\end{array}$ & Nestle Nigeria & General \\
\hline Mean & 182.031 & 32.6765 & 41.69566667 & 204.1643333 & 115014188 \\
St..Error & 8.134319704 & 1.498904173 & 1.03008184 & 5.429394678 & 5.6421122 \\
Median & 172.99 & 32.67 & 41.07 & 201.25 & 77.455 \\
Mode & 180 & 32 & 35 & 190 & 180 \\
St.Deviation & 63.01204248 & 11.6104610 & $7.97 S 979665$ & 42.05591034 & 87.407227 \\
SampleVar & 3970.517497 & 134.8028231 & 63.6641165 & 1768.699594 & 7640.0233 \\
\hline
\end{tabular}




\begin{tabular}{|c|c|c|c|c|c|}
\hline Kurtosis & 2.051442391 & -0.51054319 & -1.11249349 & 1.375864943 & 0.648343 \\
Skewness & 1.373475161 & 004754785 & 0.141811572 & 0.626221331 & 0.614207 \\
Range & 263.63 & -189 & 30.99 & 213.41 & 341.69 \\
Minimum & 92.01 & 14 & 26.01 & & 14 \\
Maximum & 355.69 & 62.9 & 57 & 133.73 & 355.69 \\
Sum & 10921.86 & 19605.9 & 2501.74 & 34714 & 2763405 \\
Count & 60 & 60 & 60 & 12249.86 & 240 \\
& & & & 60 & \\
\hline
\end{tabular}

Table 2. ARCH (2) Regression Results Dependent Variables $\boldsymbol{e}_{\boldsymbol{t}}^{2}$

\begin{tabular}{|l|c|c|c|c|}
\hline & 1 & 2 & 3 & 4 \\
\hline Intercept $\left(\propto_{0}\right)$ & 854.60 & 64.927 & 21.933 & 1168.97 \\
& $(1.375)$ & $(2.6855)^{*}$ & $(2.4309)^{*}$ & $(2.6367)^{*}$ \\
\hline $\mathrm{e}_{\mathrm{t}-1}$ & $\begin{array}{c}0.9736 \\
(7.4662)^{*}\end{array}$ & $\begin{array}{c}0.5301 \\
\mathrm{I}(3.9916)^{*}\end{array}$ & $\begin{array}{c}0.5525 \\
(4.1981)^{*}\end{array}$ & $\begin{array}{c}0.4625 \\
(3.5266)^{*}\end{array}$ \\
\hline $\mathrm{e}_{\mathrm{t}-2}^{2}$ & $\begin{array}{c}-0.1740 \\
(-1.3352)\end{array}$ & $\begin{array}{c}0.0036 \\
(0.0265)\end{array}$ & $\begin{array}{c}0.1240 \\
(0.9429)\end{array}$ & $\begin{array}{c}-0.1318 \\
(-1.007)\end{array}$ \\
\hline $\mathbb{E}^{2}$ & 0.69 & 0.25 & 0.38 & 0.15 \\
\hline $\mathrm{N}$ & 60 & 60 & 60 & 60 \\
\hline
\end{tabular}

Source: Authors' Computation, 2010.

Table 3. Stock price prediction and volatility estimation results

\begin{tabular}{|l|c|c|c|c|}
\hline \multicolumn{5}{|c|}{ Dependent variable $\mathrm{P}_{\mathrm{t}}$} \\
\hline & 1 & 2 & 3 & 4 \\
\hline Intercept $\left(\propto_{\mathrm{o}}\right)$ & 45.109 & 3.977 & 15.481 & 80.135 \\
& $(3.215)^{*}$ & $(1.831)$ & $(5.120)^{*}$ & $(5.865)^{*}$ \\
\hline $\mathrm{P}_{\mathrm{t}-1}$ & 0.9312 & 0.9431 & 0.677 & 0.634 \\
& $(7.138)^{*}$ & $(7.099)^{*}$ & $(5.336)^{*}$ & $(5.496)^{*}$ \\
\hline $\mathrm{P}_{\mathrm{t}-2}$ & -0.1759 & -0.029 & -0.029 & -0.036 \\
& $(-1.3997)$ & $(-0.244)$ & $(.256)$ & $(-0.350)$ \\
\hline $\mathrm{U}_{\mathrm{t}}^{2}$ & 0.00040 & -0.035 & -0.004 & 0.006 \\
& $(0.2037)$ & $(-2.575)$ & $(0.369)$ & $(3.580)^{*}$ \\
\hline $\mathrm{R}^{2}$ & 0.67 & 0.77 & 0.56 & 0.65 \\
\hline $\mathrm{F}$ & 41.25 & 67.89 & 26.75 & 38.08 \\
\hline $\mathrm{N}$ & 60 & 60 & 60 & 60 \\
\hline
\end{tabular}

Source: Authors' Computation, 2010.

NB: 1- Mobil stock prices, 2- First Bank stock prices, 3- Nigerian Brewery stock prices, 4- Nestle stock prices where the parenthesis represent the t-values, * indicates $5 \%$ level of significance 
Table 4. Mobil stock price volatility test (i)

\begin{tabular}{|l|r|}
\hline \multicolumn{2}{|c|}{ REGRESSION STATISTICS } \\
\hline & \\
Multiple R & 0.835434555 \\
R Square & 0.697950896 \\
Adjusted R Square & 0.687352682 \\
Standard Error & 4283701595 \\
Observations & 60 \\
\hline
\end{tabular}

Table 5. Mobil stock price volatility test (ii)

\begin{tabular}{|l|l|l|l|l|}
\hline & Coefficients & Standard Error & T Stat & P-value \\
\hline Intercept & 854.5958803 & 621.6988616 & 1.374614 & 0.174631415 \\
RESIDLAG1 2 & 0.973641853 & 0.130406224 & 7.466222 & $5.31529 \mathrm{E}-10$ \\
RESIDLAG2^2 & -0174025751 & 0.130336614 & -1335202 & 0.187118201 \\
\hline
\end{tabular}

Table 6. First bank stock price volatility test

\begin{tabular}{|l|l|l|l|l|}
\hline & Coefficients & Standard Error & T Stat & P-value \\
\hline Intercept & 64.92752363 & 24.17736575 & 2.685467238 & 0.00947002 \\
RESIDLAG1^2 & 0.530055118 & 0.13279356 & 3.991572479 & 0.0001893 \\
RESIDLAG2^2 & 0.00356774 & 0.134404113 & 0.026544873 & 0.97891546 \\
\hline
\end{tabular}

Table 7. Nigerian brewery stock price volatility test (i)

\begin{tabular}{|l|r|}
\hline \multicolumn{2}{|c|}{ REGRESSION STATISTICS } \\
\hline Multiple R & 0.637011873 \\
R Square & 0.405784126 \\
Adjusted R Square & 0.384934447 \\
Standard Error & 46.43836812 \\
Observations & 60 \\
\hline
\end{tabular}

Table 8 . Nigerian brewery stock price volatility test(ii)

\begin{tabular}{|l|l|l|l|}
\hline & Coefficients & Standard Error & $\mathrm{t}$ Stat \\
\hline Intercept & 21.93287745 & 9.02223991 & 2.430979188 \\
RESIDLAG1^2 & 0.552569908 & 0.131622251 & 4.198149645 \\
RESIDLAG2^ 2 & 0.124036619 & 0.131538421 & 0.942968739 \\
\hline
\end{tabular}

Table 9. Nestle stock price volatility test (i)

\begin{tabular}{|l|r|}
\hline \multicolumn{2}{|c|}{ REGRESSION STATISTICS } \\
\hline Multiple R & 0.426526721 \\
R Square & 0.181925044 \\
Adjusted R Square & 0.15322066 \\
Standard Error & 2871.509557 \\
Observations & 60 \\
\hline
\end{tabular}


Table 10. Nestle stock price volatility test (ii)

\begin{tabular}{|l|l|l|l|}
\hline & Coefficient & Standard Error & $t$ Stat \\
\hline Intercept & 1168.979785 & 143.3443105 & 2.63673122 \\
RESLDLAG1^2 & 0.462512442 & 0.131148605 & 3.526628768 \\
RES1DLAG2^2 & -0.131806593 & 0.1303893562 & -1.006975368 \\
\hline
\end{tabular}

Table 11. Nestle stock price prediction and volatility

\begin{tabular}{|c|c|c|c|c|c|c|}
\hline \multicolumn{7}{|c|}{ Regression Statistics } \\
\hline Multiple R & 0.819208295 & & & & & \\
\hline R Square & 0.67110223 & & & & & \\
\hline Adjusted R Square & 0.653482707 & & & & & \\
\hline Standard Error & 24.7565142 & & & & & \\
\hline Observations & 60 & & & & & \\
\hline \multicolumn{7}{|l|}{ ANOVA } \\
\hline & Df & SS & MS & $\mathrm{F}$ & & Significance $\mathrm{F}$ \\
\hline Regression & 3 & 70031.71633 & 23343.90544 & 38.086 & 759 & $1.50144 \mathrm{E}-13$ \\
\hline Residual & 56 & 34321.55974 & 612.8849954 & & & \\
\hline \multirow[t]{2}{*}{ Total } & 53 & 104353.2761 & & & & \\
\hline & Coefficients & Standard & t Stat & & & P-value \\
\hline Intercept & 80.13520921 & 13.66412116 & 5.8646 & 4223 & & $213 \mathrm{E}-07$ \\
\hline PRICE(-1) & 0.634319037 & 0.115413166 & 5.496 & 71693 & 9.88 & $53 \mathrm{E}-07$ \\
\hline PRICE(-2) & -0.035208606 & 0.103161995 & -035 & 987846 & 0.72 & 914501 \\
\hline VOLATILITY & 0.00652323 & 0.001823446 & 3.580 & 60228 & 0.00 & 718343 \\
\hline
\end{tabular}

Table 12. Nigerian Brewery stock price prediction and volatility

\begin{tabular}{|c|c|c|c|c|c|}
\hline \multicolumn{6}{|c|}{ Regression Statistics } \\
\hline $\begin{array}{c}\text { Multiple R } \\
\text { R Square } \\
\text { Adj R Square } \\
\text { Stand Error } \\
\text { Observations }\end{array}$ & $\begin{array}{c}0.767462531 \\
0.588998737 \\
0.566980812 \\
5.250503215 \\
60\end{array}$ & & & & \\
\hline \multicolumn{6}{|l|}{ ANOVA } \\
\hline & Df & SS & MS & $\mathrm{F}$ & Significance $\mathrm{F}$ \\
\hline $\begin{array}{l}\text { Regression } \\
\text { Residual } \\
\text { Total }\end{array}$ & $\begin{array}{c}3 \\
56 \\
59\end{array}$ & $\begin{array}{r}2212.386969 \\
1543.795904 \\
3756.182873 \\
\end{array}$ & $\begin{array}{l}737.462323 \\
27.56778401\end{array}$ & 26.75087 & 7.23741E-11 \\
\hline & Coefficients & Standard & & T Stat & P-value \\
\hline $\begin{array}{c}\text { Intercept } \\
\text { PRICE(-1) } \\
\text { PRICE (-2) } \\
\text { VOLATILITY }\end{array}$ & $\begin{array}{c}15.48115063 \\
0.67721594 \\
-0.028754064 \\
-0.0044103458\end{array}$ & $\begin{array}{c}3023245804 \\
0.12689905 \\
0.112396942 \\
0.011921832\end{array}$ & & $\begin{array}{r}5.120705241 \\
5.336650988 \\
0.255826033 \\
-0369360826\end{array}$ & $\begin{array}{c}3.88 \mathrm{E}-05 \\
1.77 \mathrm{E}-06 \\
0.799023 \\
0.713252\end{array}$ \\
\hline
\end{tabular}


Table13. First bank stock price prediction and volatility

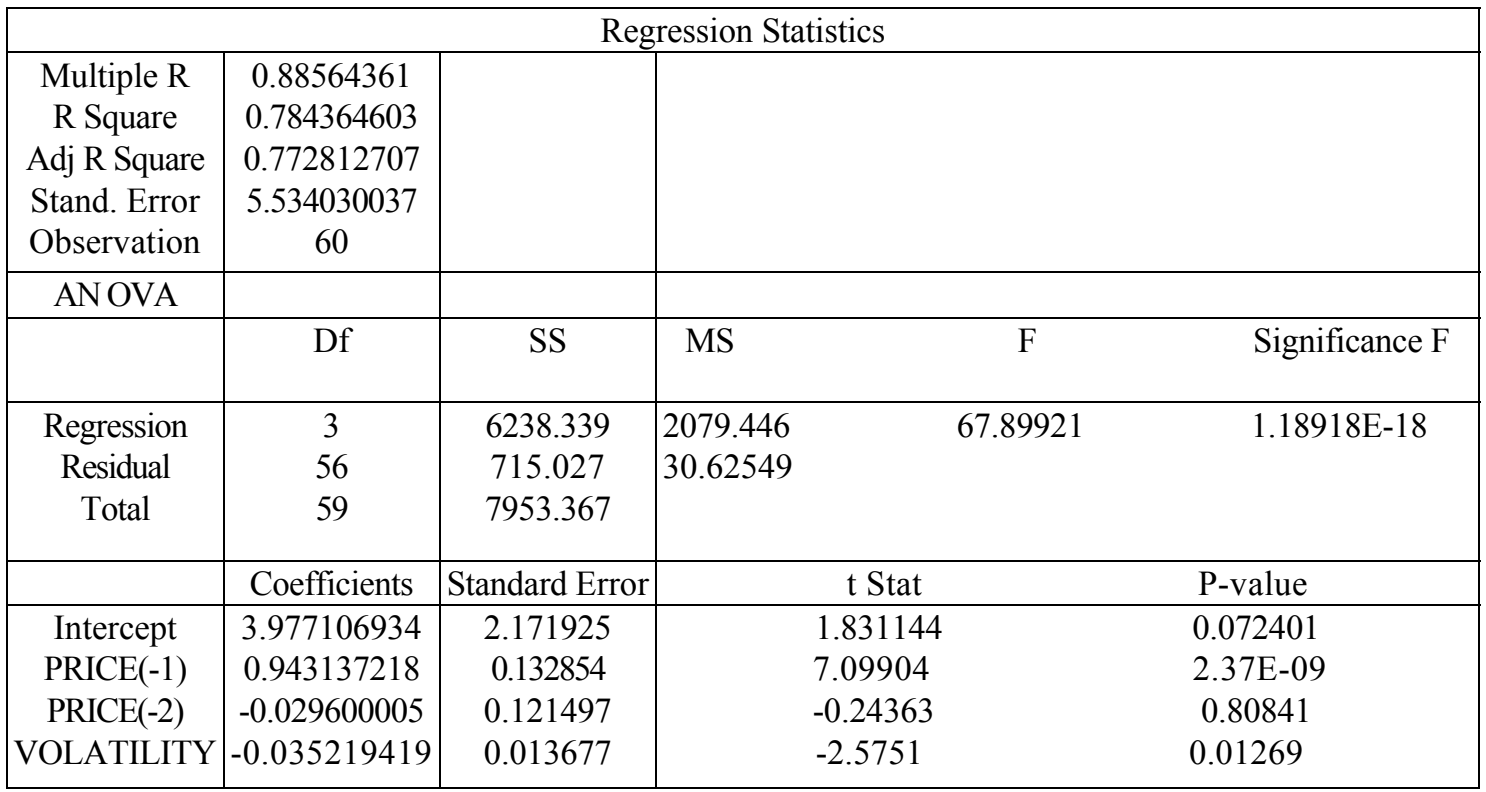

Table14. Mobil stock price prediction and volatility

\begin{tabular}{|c|c|c|c|c|c|}
\hline \multicolumn{6}{|c|}{ Regression Statistics } \\
\hline $\begin{array}{c}\text { Multiple R } \\
\text { R Square } \\
\text { Adj R Square } \\
\text { Standard Error } \\
\text { Observations }\end{array}$ & $\begin{array}{c}0.829730457 \\
0.688465908 \\
0.671776581 \\
36.10009455 \\
60\end{array}$ & & & & \\
\hline \multicolumn{6}{|l|}{ ANOVA } \\
\hline & Df & SS & MS & $\mathrm{F}$ & Significance $\mathrm{F}$ \\
\hline $\begin{array}{c}\text { Regression } \\
\text { Residual } \\
\text { Total }\end{array}$ & $\begin{array}{c}3 \\
56 \\
59\end{array}$ & $\begin{array}{c}161280.39 \\
72980.1423 \\
234260.5323\end{array}$ & $\begin{array}{l}53760.13 \\
1303.217\end{array}$ & 41.25187 & $3.32836 \mathrm{E}-14$ \\
\hline & Coefficients & Standard Error & & t Stat & P-value \\
\hline $\begin{array}{c}\text { Intercept } \\
\text { PRICE (1) } \\
\text { PRICE(-2) } \\
\text { VOLATILITY }\end{array}$ & $\begin{array}{l}45.10962025 \\
0.931234222 \\
-0175361552 \\
0.000403415\end{array}$ & $\begin{array}{c}14.03121246 \\
0.130467133 \\
0.125643313 \\
0.001980408\end{array}$ & & $\begin{array}{c}3.214948 \\
7.137692 \\
-1.39969 \\
0.203703\end{array}$ & $\begin{array}{l}0.002167 \\
2.05 \mathrm{E}-09 \\
0.167122 \\
0.839324\end{array}$ \\
\hline
\end{tabular}

